В. О. Подліпаєв ${ }^{1}$, В. О. Шумейко ${ }^{1}$, О. В. Атрасевич ${ }^{1}$, І. А. Хижняк ${ }^{2}$

${ }^{1}$ Інститут телекомунікацій та глобального інформаційного простору НАН України, Київ, Україна

${ }^{2}$ Харківський національний університет Повітряних Сил імені І. Кожедуба, Харків, Україна

\title{
СТВОРЕННЯ МОБІЛЬНОЇ АВТОМАТИЗОВАНОЇ СИСТЕМИ ЗБОРУ ГЕОПРОСТОРОВИХ ДАНИХ ТА ВЕДЕННЯ ГЕОПРОСТОРОВОГО АНАЛІЗУ ДЛЯ ВИРІШЕННЯ ЗАВДАНЬ НАЦІОНАЛЬНОЇ БЕЗПЕКИ І ОБОРОНИ
}

\begin{abstract}
Предметом вивчення в статті є автоматизовані системи геопросторового аналізу для вирішення завдань національної безпеки і оборони. Метою є створення мобільної автоматизованої системи збору геопросторових даних та ведення геопросторового аналізу. Завдання: аналіз вимог, які висуваються до інформаційно-аналітичних систем; розгляд структури автоматизованої системи геопросторового аналізу; висунення вимог до автоматизованої системи геопросторового аналізу; визначення завдань, які вирішуються за допомогою автоматизованої системи геопросторового аналізу; визначення класів автоматизованих систем геопросторового аналізу, в залежності від їх розміщення; аналіз світового досвіду при прийнятті рішень у складаній оперативній обстановці; створення мобільної автоматизованої систем збору геопросторових даних та ведення геопросторового аналізу; визначення функціональних можливостей комплексу. Використовуваними методами є: методи аналізу і синтезу складних інформаційних систем, методи декомпозиції багаторівневого моделювання. Отримані такі результати. Створення мобільних автоматизованих систем (комплексів) збору геопросторових даних та ведення геопросторового аналізу. Функціональні можливості комплексу дозволяють на місці збирати, систематизувати та обробляти всі необхідні геопросторові дані та надавати результати їх обробки споживачу. Висновки. Тактико-технічні характеристики та технологічні можливості зазначеного мобільного комплексу забезпечують прийняття рішення у відповідних умовах, а самі комплекси можуть бути використані для забезпечення як окремих пунктів управління, так й бути елементами складних систем управління вищих рівнів.
\end{abstract}

Кл юч ов і слов а: геопросторовий аналіз, національна безпека і оборона, автоматизована система, інформаційноаналітична система, геопросторові дані, мобільний комплекс, геоінформаційна система.

\section{Вступ}

Постановка проблеми. Відповідно до Закону України “Про національну безпеку України”: “Національна безпека України - захищеність державного суверенітету, територіальної цілісності, демократичного конституційного ладу та інших національних інтересів України від реальних та потенційних загроз" [1].

Використання інформаційних технологій в сфері національної безпеки дозволяс оперативно отримувати інформацію, а комплексний підхід (використання декількох джерел) дозволяє підвищити її достовірність.

3 цією метою, в провідних країнах світу постійно вдосконалюються сили, засоби та способи добування інформації, а також аналіз отриманих даних і доведення їх до органів державного (військового) керівництва [2].

Впровадження сучасних інформаційно-аналітичних систем, які спроможні формувати відповідну інформацію в реальному масштабі часу, дозволяють приймати ефективні управлінські рішення [3].

Аналіз останніх досліджень і публікацій. Класифікація автоматизованих систем управління в провідних країнах світу передбачає їх поділ на декілька класів в залежності від функцій, які виконує відповідна система:

command (команда);

control (контроль);

communications (комунікаціi);

computers (комп'ютери); intelligence (інтелект);

surveillance (спостереження);

reconnaissance (розвідка).

Вимоги, які висуваються до інформаційноаналітичних систем:

відображення та передача завдань 3 використанням єдиної обчислювальної системи 3 необхідним рівнем захисту;

автоматизований збір, обробка інформації та визначення місцеположення об'єктів інтересу з відображенням на електронній карті;

оцінка та опис місцевості, природних та техногенних об'єктів;

проведення геопросторового аналізу;

відпрацювання варіантів рішення та моделювання з використанням цифрових карт;

розробка планувальних документів та звітних інформаційних документів.

Особливе місце в системі національної безпеки займає процес добування, збору, систематизації, обробки та управління геопросторовими даними (дані дистанційного зондування Землі, отримані 3 космічних і повітряних платформ, наземного спостереження, радіоперехоплення, з відкритих джерел та інші) [4].

Цей процес $є$ безперервним, що обумовлено постійними змінами в оперативній обстановці, які пов'язані з діяльністю людини та впливом природних явищ.

Здатність точно прив'язувати операційні райони та події, що в них відбуваються, у просторі та провести геопросторовий аналіз забезпечує необхідні умови для ефективного управління силами i 
засобами (підготовки засобів ураження, планування польотів на малих висотах, використання маскуючих і демаскуючих властивостей місцевості, вирішувати інженерні задачі тощо) [5].

Структура автоматизованої системи геопросторового аналізу:

апаратне забезпечення;

програмне забезпечення;

інформація (база даних);

аналітичні алгоритми;

обслуговуючий персонал.

Вимоги, які висуваються до автоматизованої системи геопросторового аналізу:

багатофункціональність та простота у користуванні;

надійність та забезпечення необхідного ступеню захисту;

можливість інтеграції (сумісності) 3 іншими системами.

Завдання, які вирішуються за допомогою автоматизованої системи геопросторового аналізу:

робота в єдиному стандарті даних;

створення єдиної бази геопросторових даних 3 функцією віддаленої реплікації;

представлення оперативного доступу до баз геопросторових даних, сервісів обробки даних і спеціальних програм;

візуалізація результатів геопросторового аналізу з можливістю пошуку, моделювання та створення звітних документів;

забезпечення необхідного ступеню захисту інформації через розмежування прав доступу.

Автоматизовані системи геопросторового аналізу, в залежності від їх розміщення, поділяються на три основні класи:

стаціонарний - призначений для розгортання ситуаційного центру в пунктах постійної дислокації та вирішення завдань загального аналізу інформації та планування задіяння сил та засобів;

мобільний - призначений для забезпечення оперативної обробки та аналізу інформації безпосередньо в зоні проведення операції;

вбудований - призначений для встановлення на роботизованих машинах та представляє собою комплект спеціального програмного продукту.

Особливої уваги потребує забезпечення такими системами процесів оперативного прийняття рішень в складних умовах.

Метою статті є питання створення мобільної автоматизованої системи збору геопросторових даних та ведення геопросторового аналізу.

\section{Виклад основного матеріалу}

В регіонах безпосереднього розвитку подій створюються командні пункти, які обладнані мобільними інтегрованими системами управління. Важливим компонентом таких систем повинно бути можливість збору й обробки різнорідної геопросторової інформації для відображення оперативної обстановки у цьому районі, а також проведення геопросторового аналізу для забезпечення прийнятті управлінських рішень [6].
В оперативній обстановці рішення приймаються на місті подій або у безпосередній близькості до них та за певними обмеженнями, такими як час, постійна передислокація, особливості прийомупередачі даних, обсяг додаткової інформації тощо.

Світовий досвід показує, що основними труднощами прийняття рішення у складаній оперативній обстановці, особливо на тактичній ланці, є:

відсутність математично коректних алгоритмів оцінки дій військ на тактичному рівні, зважаючи на величезну різноманітність способів та прийомів, що застосовуються під час виконання бойових задач;

складність створення автоматизованою системи збору та оцінки даних тактичної обстановки 3 огляду на дуже велику різноманітність ії параметрів та швидкоплинності змін (у порівнянні з оперативною ланкою управління);

виникнення, у разі чого, необхідності ручної роботи зі збору, обробці та відображення великої кількості змінних даних, що перевищує можливості відповідних посадових осіб у питанні введення таких даних в систему;

необхідність обробки відносно великої кількості даних за одиницю часу, які за своїм об'ємом наразі перевищують можливості технічного забезпечення, що використовується на тактичній ланці управління;

складність створення самоорганізуючих мереж зв'язку та надійних локальних мереж (систем передачі даних) між великою кількістю високомобільних об'єктів управління.

У зв'язку з цим постає актуальне питання створення таких автоматизованих систем геопросторового аналізу, які б у достатній мірі забезпечували процес оперативного прийняття рішення та були адаптивні до умов, в яких ці рішення приймаються (бойові дії, надзвичайні ситуації, роботи безпосередньо на об'єкті тощо).

Вирішенням цього питання є створення мобільних автоматизованих систем (комплексів) збору геопросторових даних та ведення геопросторового аналізу.

Рухливість системи та наявність у іiі складі засобів добування і збору геопросторових даних (безпілотні літальні апарати, планшети реєстрації даних на місцевості тощо, які представлені на рис. 1), забезпечують можливість знаходження у епіцентрі подій та оперативного отримання найактуальнішої інформації. Крім того, маневреність значно підвищує ії живучість.

Потужні програмно-технічні засоби у мобільному виконанні (рис. 2), дозволяють швидко обробляти та аналізувати значні обсяги отриманих геопросторових даних, а також виготовляти різноманітні спеціалізовані геоінформаційні продукти.

Базовий програмний продукт комплексу має наступні потужні функціональні особливості:

працює на різних комп'ютерних платформах, легко інтегрується з іншими прикладними системами та програмами, підтримує практично всі розповсюджені програмні розробки та нові апаратні засоби; 


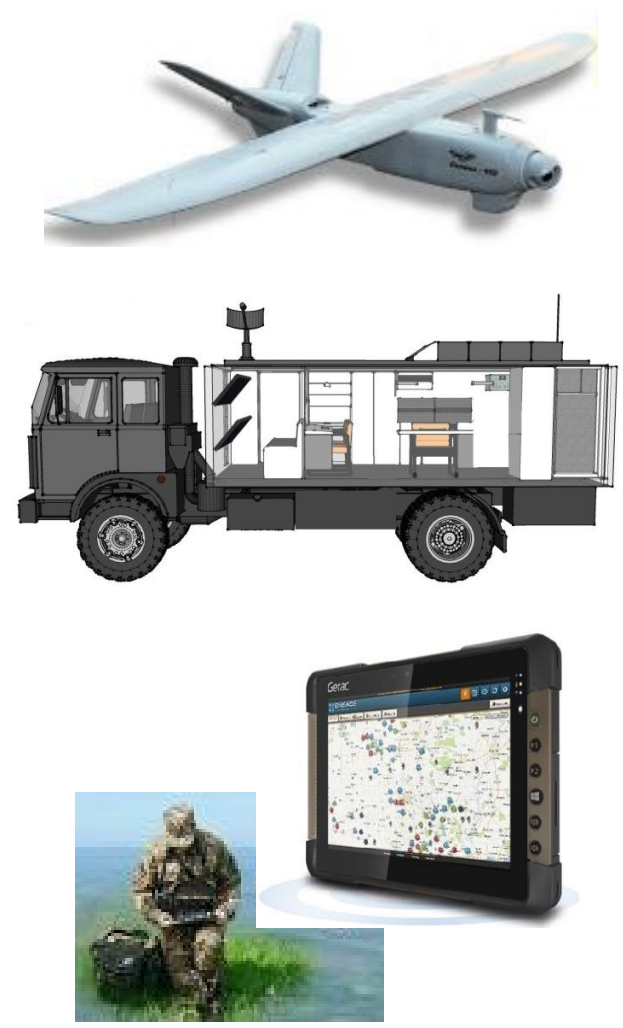

Рис. 1. Засоби добування і збору геопросторових даних та мобільна база комплексу
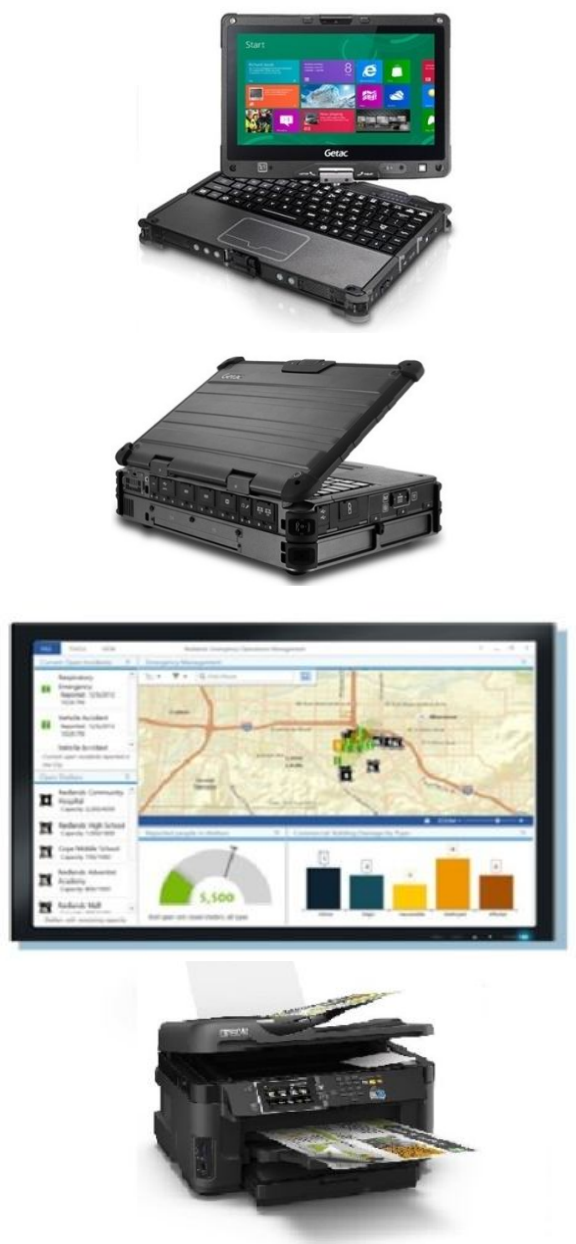

Рис. 2. Програмно-технічні засоби у мобільному виконанні об’єднує просту в роботі модель даних з повнофункціональним набором засобів обробки та аналізу геопросторової інформації, що відповідають сучасним вимогам;

ця модель здатна об'єднувати дані різного типу: растрові й векторні, зображення, табличні дані, рельєф, відео тощо в рамках єдиної системи;

повністю сумісний 3 основними форматами обміну даними, що використовуються військовими відомствами більшості країни світу, а також з іншими, які застосовуються у різних сферах людської діяльності (понад 150).

Створені на основі цього програмного продукту ГІС дозволяють створювати більш реалістичні моделі бойової обстановки, що, в свою чергу, збільшує боєздатність військових підрозділів та командування за рахунок значних скорочень часу на підготовку пропозицій для прийняття рішень на застосування військ та засобів ураження [7].

Обладнання таких комплексів засобами супутникового зв'язку (рис. 3), забезпечує стійкий, захищений канал обміну даними за трьома рівнями взаємодії: верхні органи управління; підпорядковані сили і засоби збору геопросторових даних; аналогічні комплекси (такого же рівня) на сусідніх територіях.

За таких умов забезпечується збір інформації в польових умовах на великій відстані до центру керування операцією (бойовими діями), а також попереднє їі оброблення “на марші” практично в режимі приближеному до реального часу, а за необхідністю, приймати рішення на місці.
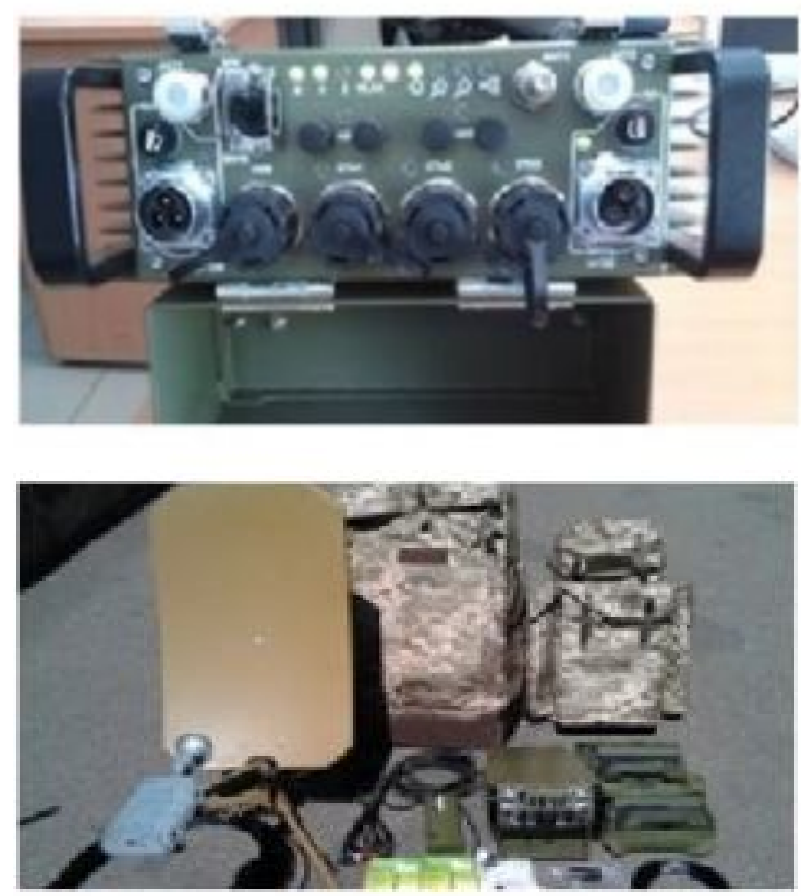

Рис. 3. Засоби супутникового зв'язку та обміну даними (у мобільному виконанні)

Комплексна робота програмно-технічних засобів 3 засобами супутникового зв'язку дозволяє в онлайн режимі отримувати геопросторові дані від 
різних джерел та використовувати дані з різних інформаційних ресурсів, незважаючи на їх територіальне розташування.

Функціональні можливості комплексу дозволяють на місці збирати, систематизувати та обробляти всі необхідні геопросторові дані (рис. 4) та на-

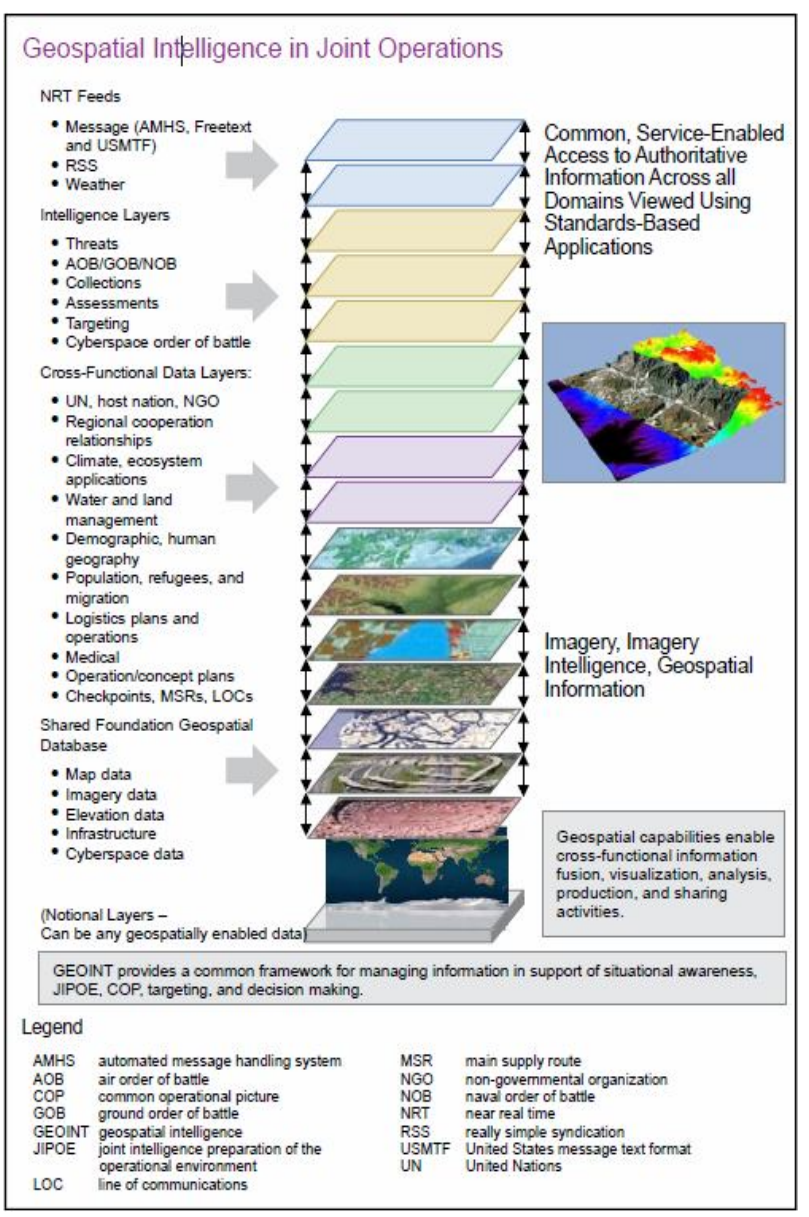

давати результати їх обробки споживачу (органам військового управляння, розвідці, командирам різних рівнів).

Також $є$ можливість забезпечувати споживачів результатами обробки даних та тематичними картами у друкованому вигляді [78].

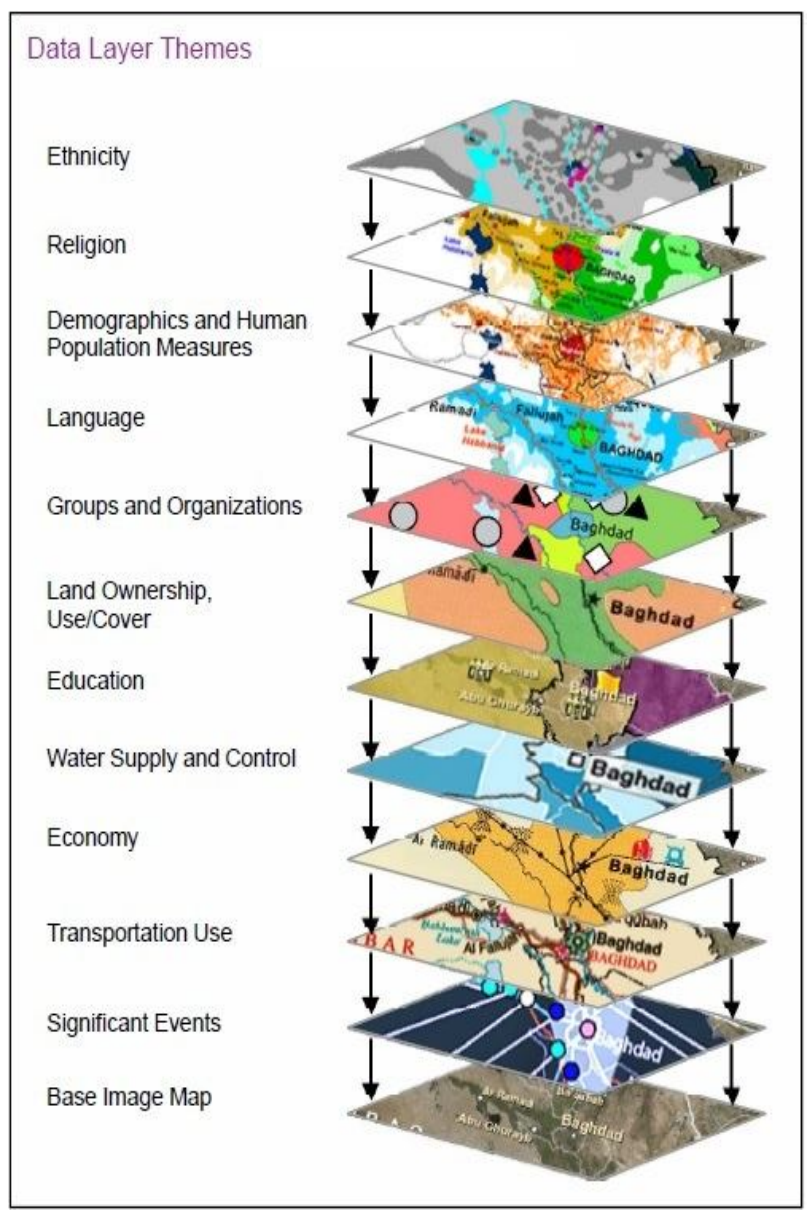

Рис. 4. Інформаційні ресурси, які створюються та надаються за результатами збору геопросторових даних та проведення геопросторового аналізу

Зазначений комплекс може використовуватися у складі розвідувальних та аналітичних підрозділів штабів різного рівня, в системах геоінформаційної підтримки, інформаційно-аналітичних та інших системах, що використовують геопросторові дані.

Найбільша ефективність й найвища оперативність проведення геопросторового аналізу та отримання його результатів забезпечується тісним поєднання інформації з різних видів розвідки та актуальних геопросторових даних про район ведення бойових дій, виникнення кризової ситуації або інші райони інтересу, за допомогою сучасних інформаційних технологій збору, обробки та передачі даних.

\section{Висновки}

Таким чином, тактико-технічні характеристики та технологічні можливості зазначеного мобільного комплексу забезпечують прийняття рішення у відповідних умовах, а самі комплекси можуть бути використані для забезпечення як окремих пунктів управління, так й бути елементами складних систем управління вищих рівнів.

Спираючись на результати дослідження світового досвіду розвитку даного питання й часу, 3 якого це питання стало актуальними та вирішується, можна 3 впевненістю стверджувати, що таки комплекси вже $\epsilon$ обов'язковим елементом системи управління. Тому для Збройних Сил України це не $\epsilon$ створенням щось нового у світі, а $\epsilon$ прагнення відповідати сучасним стандартам й вимогам до систем управління у сфері національної безпеки і оборони.

Результати зазначених досліджень та їх аналіз детальніше будуть розглянуті у подальших публікаціях, а зараз лише зазначимо, що подібні мобільні комплекси вже мають на озброєні Збройні Сили Сполучених Штатів Америки, Великобританії, Російської Федерації, Республіки Білорусь та інших провідних та суміжних з Україною держав. 
1. Закон України “Про національну безпеку України” № 2469-VIII від 21.06.2018. Режим доступу: http://zakon.rada.gov.ua/laws/show/2469-19.

2. Joint Intelligence // JP 2-00, Joint Publication, 22 October 2013.

3. Коваленко А.А. Сучасний стан та тенденції розвитку комп'ютерних систем об'єктів критичного застосування / А.А. Коваленко, Г.А. Кучук // Системи управління, навігації та зв'язку. - Полтава . ПНТУ, 2018. - Вип. 1(47). C. $110-113$.

4. Попов М. О., Серединін С. С. Геоінформаційні системи та технології в завданнях оборони й національної безпеки // Наука і оборона.- 2009.-- №3.- С. 49-56.

5. Попов М.О. Геопросторова розвідка в операціях збройних сил / Попов М.О. // Наука і оборона. - 2010. - № 2. C. $30-39$.

6. Геопросторова розвідка, як шлях реалізації геоінформаційного підходу у комплексній обробці розвідувальної інформації / В.О. Подліпаєв // Системи обробки інформації. - 2013. - № 5(112). - С. 53-55.

7. Створення бази геопросторових даних об'єктів розвідки з використанням даних дистанційного зондування Землі та геоінформаційних систем / І.А. Кухарський, В.О. Подліпаєв, О.В. Атрасевич, В.О. Шумейко // Системи озброєння і військова техніка. - 2013. - № 2(34). - С. 111-113.

8. Geospatial Intelligence in Joint Operations // JP 2-03, Joint Publication, 5 July 2017.

Рецензент: д-р техн. наук, професор Г. В. Худов, Харківський національний університет Повітряних Сил імені Івана Кожедуба, Харків. Received (Надійшла) 11.10.2018 Accepted for publication (Прийнята до друку) 05.12.2018

\section{Создание мобильной автоматизированной системы сбора геопространственных данных и ведения геопространственного анализа для решения задач национальной безопасности и обороны}

В. О. Подлипаев, В. О. Шумейко, О. В. Атрасевич, И. А. Хижняк

Предметом изучения в статье являются автоматизированные системы геопространственного анализа для решения задач национальной безопасности и обороны. Целью является создание мобильной автоматизированной системы сбора геопространственных данных и ведения геопространственного анализа. Задачи: анализ требований, предъявляемых к информационно-аналитическим системам; рассмотрение структуры автоматизированной системы геопространственного анализа; предъявление требований к автоматизированной системе геопространственного анализа; определение задач, которые решаются с помощью автоматизированной системы геопространственного анализа; определения классов автоматизированных систем геопространственного анализа, в зависимости от их размещения; анализ мирового опыта при принятии решений в сложившейся оперативной обстановке; создание мобильной автоматизированной системы сбора геопространственных данных и ведения геопространственного анализа; определение функциональных возможностей комплекса. Используемыми методами являются: методы анализа и синтеза сложных информационных систем, методы декомпозиции многоуровневого моделирования. Получены следующие результаты. Создание мобильных автоматизированных систем (комплексов) сбора геопространственных данных и ведения геопространственного анализа. Функциональные возможности комплекса позволяют на месте собирать, систематизировать и обрабатывать все необходимые геопространственные данные и предоставлять результаты их обработки потребителю. Выводы. Тактико-технические характеристики и технологические возможности указанного мобильного комплекса обеспечивают принятие решения в соответствующих условиях, а сами комплексы могут быть использованы для обеспечения как отдельных пунктов управления, так и быть элементами сложных систем управления высших уровней.

Ключевые слова: геопространственный анализ, национальная безопасность и оборона, автоматизированная система, информационно-аналитическая система, геопространственные данные, мобильный комплекс, геоинформационная система.

\section{Creation of a mobile automatic geo-space data collaboration system and the geospatial analysis for the settlement of national securityand defense objectives \\ V. Podlipaev, V. Shumeiko, O. Atrasevich, I. Khyzhniak}

The subject matter of the article is automated geospatial analysis systems for solving problems of national security and defense. The goal is to create a mobile and automated system, for collecting geospatial data and conducting geospatial analysis. Tasks; analysis of requirements for information and analytical systems; consideration of the structure of the automated system of geospatial analysis; nomination of requirements for an automated system of geospatial analysis; definition of tasks, which are solved by means of the automated system of geospatial analysis; definition of classes of automated systems of geospatial analysis, depending on their location; analysis of world experience in decision making in folding operational environment; creation of mobile automated systems for collecting geospatial data and conducting geospatial analysis; definition of the functional capabilities of the complex. The methods used are: methods for analyzing and synthesizing complex information systems, methods for decomposing multilevel modeling. The following results were obtained; Creation of mobile automated systems (complexes) of geospatial data collection and geospatial analysis. The functionality of the complex allows you to collect, organize and process all the necessary geospatial data on-site and provide the results of their processing to the consumer. Conclusions. The tactical and technical characteristics and technological capabilities of the specified mobile complex provide decision making in appropriate conditions. The complexes themselves can be used to provide both individual control points and be elements of complex control systems of higher levels.

Keywords: geospatial analysis, national security and defense, automated system, information and analytical system, geospatial data, mobile complex, geoinformation system. 